\title{
Prevalence of Medication-Related Osteonecrosis of the Jaw in Patients with Breast Cancer, Prostate Cancer, and Multiple Myeloma
}

\author{
Petra Rugani ${ }^{1, *}$, Christian Walter ${ }^{2}$, Barbara Kirnbauer ${ }^{1}$, Stephan Acham ${ }^{1}$, \\ Yvonne Begus-Nahrman ${ }^{3}$ and Norbert Jakse ${ }^{1}$ \\ 1 Divison of Oral Surgery and Orthodontics, Medical University of Graz, 8010 Graz, Austria; \\ barbara.kirnbauer@medunigraz.at (B.K.); stephan.acham@medunigraz.at (S.A.); \\ norbert.jakse@medunigraz.at (N.J.) \\ 2 Oral and Maxillofacial Surgery of the Mediplus Clinic, 55128 Mainz, Germany; walter@mainz-mkg.de \\ 3 Konzept Pharma Service GmbH, 31084 Freden, Germany; y.begus-nahrmann@konzept-pharma-service.de \\ * Correspondence: petra.rugani@medunigraz.at; Tel.: +43-316-385-13989
}

Academic Editor: Patrick Schmidlin

Received: 2 August 2016; Accepted: 19 September 2016; Published: 27 September 2016

\begin{abstract}
Medication-related osteonecrosis of the jaw is a known side-effect of antiresorptive therapy in patients with malignant diseases. Nevertheless, the exact pathogenesis is still unknown and published prevalences show a significant range. The aim of the presented paper was to assess the prevalence of osteonecrosis (ONJ) in breast cancer, prostate cancer, and multiple myeloma patients receiving parenteral antiresorptive therapy. For this reason a PubMed search was performed and 69 matching articles comprising 29,437 patients were included in the analysis. Nine-hundred fifty-one cases of jaw necrosis were described. The overall ONJ-prevalence was $2.09 \%$ in the breast cancer group, $3.8 \%$ in the prostate cancer group, and $5.16 \%$ for multiple myeloma patients.
\end{abstract}

Keywords: osteonecrosis; bisphosphonate; denosumab; multiple myeloma; breast cancer; prostate cancer

\section{Introduction}

In 2003 Robert E. Marx reported on 36 cases of non-healing painful bone exposure in the mandible, maxilla, or both, that were unresponsive to surgical or medical treatments in patients treated with bisphosphonates as a growing epidemic [1].

This causal association was cautiously denied in a letter by Tarassof and Csermak representing Novartis, given the fact that no such reports had occurred in multiple, well-controlled clinical trials of more than 3000 cancer patients that had been conducted as far back as the early 1990s [2].

To date jaw necrosis linked to antiresorptive therapy is an accepted side effect and no longer a matter of discussion.

In 2007 bisphosphonate-related osteonecrosis of the jaw (BRONJ) has been primarily defined as a condition of exposed, necrotic bone in the maxillofacial region that has persisted for more than eight weeks in patients who have received or are receiving treatment with bisphosphonates and have no history of radiation therapy of the jaws [3]. This definition relies on a combination of various symptoms in combination with the patient's anamnesis. Even though the condition was firstly described over ten years ago, the underlying principles of pathogenesis are not conclusively clarified yet. Common theories deal with reduced bone remodeling, impairment of local vascularization, and neoangiogenesis [4], accumulation of microcracks in devitalized bone with empty osteocyte lacunae [5], and infection of bone via osteoclast-independent bone resorption [6,7]. 
Three stages were specified, the main symptom being frank bone exposure in the maxillofacial region [8]. In addition, an "at-risk category" was defined for patients who have been treated with either oral or intravenous bisphosphonates, but show no apparent exposed/necrotic bone.

As experience grew in this condition, clinicians recognized that bisphosphonate-exposed patients can show clinical and radiological signs potentially indicating osteonecrosis lacking the cardinal symptom of exposed bone in the maxillofacial region. Therefore, the AAOMS updated its classification and added a stage 0 category, implying patients who show nonspecific clinical and radiological findings or symptoms that possibly correlate to osteonecrosis. These findings must not be explicable by other conditions [3]. As a study by Fedele et al. showed that patients who present BRONJ stage 0 may be at high risk of developing advanced stages of BRONJ [9], the relevance of an early diagnosis increased. It has to be mentioned that the AAOMS classification of 2009 categorized bone exposure via fistulas stage 0 , implying that no invasive treatment is needed in such cases. This was revised in 2013, when each bony exposure fulfilling the criteria was counted as evident bone necrosis, no matter the extent. Furthermore, the term BRONJ was changed to MRONJ (medication-related osteonecrosis of the jaw) taking into account other pharmaceuticals that might cause jaw necrosis besides bisphosphonates.

Consequently, published prevalences of BRONJ were steadily increasing [10-13] since this update from 2009 and 2013, augmented by MRONJ cases due to therapy with Denosumab, or antiangiogenic agents like Bevazicumab or Sunitinib.

In general the incidence rate is higher in patients with intravenous administration of bisphosphonates compared to the oral route of administration. The estimates of MRONJ for intravenous application range from around $1 \%[14,15]$ to $21 \%$ for sub-clienteles [16], but even after more than 10 years since this condition was reported there is still some lack of knowledge. The main reasons therefore are probably:

Many patients are asymptomatic for a long time and, thus, may not be diagnosed or do not relate their oral symptoms to the antiresorptive therapy.

People suffering from MRONJ have various underlying diseases. They present a heterogeneous group of patients treated by independent medical specialists. A standardized oral investigation of patients at risk has still not been implemented to date. As a consequence, the definite prevalence might be higher, as demonstrated by Walter et al. [16], who showed that prevalence of BRONJ is underestimated if thorough inspection of the oral cavity is omitted.

The condition is influenced by several risk factors, such as drug potency, type of administration, as well as individual local and systemic conditions. In many cases patients receive multiple agents that interfere with bone metabolism and may, therefore, cause or benefit the development of osteonecrosis.

\section{Objectives}

To review published prevalences of ONJ in patients with the primary diseases of breast cancer, prostate cancer, and multiple myeloma, receiving parenteral antiresorptive therapy (bisphosphonates, denosumab).

\section{Methods}

We performed a PubMed literature search using the terms: "osteonecrosis", "incidence", "prevalence", "bisphosphonate", and "denosumab".

Inclusion criteria were: the type of primary cancer: breast cancer, multiple myeloma, or prostate cancer; parenteral antiresorptive therapy with bisphosphonate or denosumab; and a size of patient collective of at least 10 patients.

Exclusion criteria were: review papers; duplicated articles; integrated analyses of already reported studies; and animal studies.

The reports were screened for prevalence rates, and data concerning primary disease and used antiresorptive therapy were collected.

Data analysis was performed concerning the following questions: 
- What is the prevalence of osteonecrosis (ONJ) relating to primary disease?

- What are the prevalences before and after the adaptions of the AAOMS classification in 2009?

To assess the overall ONJ prevalence patients were grouped according to primary disease. Thus, positive ONJ cases were weighted against the total number of patients of all included studies.

\section{Results}

One-hundred forty-one articles were found. Fifty-eight papers were excluded right away after screening of abstracts because of improper article type (review papers, case reports, prevalence not reported) or inappropriate primary disease (osteoporosis, rheumatoid arthritis, giant cell carcinoma, other cancer types).

Fifteen further manuscripts were excluded after studying the full papers. The reasons therefore were:

- Study population not described in sufficient detail;

- Primary disease for each ONJ case not assignable;

- Oral administration route;

- Double reports;

- Combined analysis of other trials;

- Estimation of prevalence; and

- Special risk situation due to performed intervention.

Sixty-eight reports comprising 29,437 patients were included in the analysis (Table 1).

Amongst those, 41 were published before 2009 (13,059 patients) and 27 since 2010 (16,378 patients). Of the total patients, 16,632 suffered from breast cancer, 4236 from prostate cancer, and 8569 from multiple myeloma.

Nine-hundred fifty-one cases of jaw necrosis were described. Amongst those, 348 had breast cancer, 161 had prostate cancer, and 442 suffered from multiple myeloma (Table 2).

Thus, the overall ONJ-prevalence was $2.09 \%$ in the breast cancer group, 3.8\% in the prostate cancer group, and $5.16 \%$ for multiple myeloma patients.

Table 1. Included studies.

\begin{tabular}{|c|c|c|c|c|c|c|c|}
\hline Year & Author & Study Design & Disease & $\begin{array}{l}\text { Patients } \\
\text { (n) }\end{array}$ & $\begin{array}{l}\text { ONJ } \\
\text { Cases }\end{array}$ & $\begin{array}{c}\text { Prevalence } \\
(\%)\end{array}$ & Used Agent \\
\hline \multirow{6}{*}{2005} & \multirow{3}{*}{ Bamias [17] } & pros & breast ca & 70 & 2 & 2.86 & $\mathrm{Z}, \mathrm{PZ}, \mathrm{ZI}$ \\
\hline & & pros & mult myel & 111 & 11 & 9.91 & $\mathrm{Z}, \mathrm{PZ}, \mathrm{ZI}$ \\
\hline & & pros & prostate ca & 46 & 3 & 6.52 & $\mathrm{Z}, \mathrm{PZ}, \mathrm{ZI}$ \\
\hline & \multirow{2}{*}{ Durie [18] } & web survey & mult myel & 904 & 62 & 6.86 & $\mathrm{Z}, \mathrm{P}$ \\
\hline & & web survey & breast ca & 299 & 13 & 4.35 & \\
\hline & Guarneri [19] & retro & breast ca & 48 & 3 & 6.25 & $\mathrm{P}$ \\
\hline \multirow{7}{*}{2006} & Badros [20] & retro & mult myel & 340 & 11 & 3.24 & $\mathrm{P}, \mathrm{Z}, \mathrm{PZ}$ \\
\hline & Calvo-Villas [21] & retro & mult myel & 64 & 7 & 10.94 & Z \\
\hline & Dimopoulos [22] & pros & mult myel & 202 & 15 & 7.43 & $\mathrm{Z}$ \\
\hline & Sanna [23] & pros & breast ca & 81 & 5 & 6.17 & $\mathrm{P}, \mathrm{Z}$ \\
\hline & Tosi [24] & retro & mult myel & 259 & 9 & 3.47 & Z \\
\hline & Zervas [25] & pros & mult myel & 254 & 28 & 11.02 & $\mathrm{Z}, \mathrm{P}, \mathrm{ZP}$ \\
\hline & Ortega [26] & $?$ & breast ca & 126 & 2 & 1.59 & Z \\
\hline \multirow{11}{*}{2007} & Aguiar Bujanda [27] & css & breast ca & 35 & 4 & 11.43 & Z \\
\hline & Corso $[28]$ & retro & mult myel & 106 & 8 & 7.55 & $\mathrm{Z}, \mathrm{PZ}$ \\
\hline & García Sáenz [29] & pros & prostate ca & 104 & 3 & 2.88 & Z \\
\hline & Jadu [30] & retro & mult myel & 655 & 21 & 3.21 & $\mathrm{P}$ \\
\hline & Ortega [31] & retro & prostate ca & 52 & 6 & 11.54 & Z \\
\hline & Petrucci [32] & $?$ & mult myel & 311 & 22 & 7.07 & $\mathrm{Z}, \mathrm{P}, \mathrm{PZ}$ \\
\hline & \multirow{3}{*}{ Wang [33] } & retro & mult myel & 292 & 11 & 3.77 & $\mathrm{Z}, \mathrm{P}, \mathrm{Z}$ \\
\hline & & retro & breast ca & 81 & 2 & 2.47 & $\mathrm{Z}, \mathrm{P}, \mathrm{Z}$ \\
\hline & & retro & prostate ca & 69 & 2 & 2.9 & $\mathrm{Z}, \mathrm{P}, \mathrm{Z}$ \\
\hline & Lipton [34] & prosp & breast ca & 211 & 0 & 0 & $\mathrm{D}$ \\
\hline & Pozzi [35] & retro & mult myel & 1402 & 28 & 2 & $\mathrm{Z}, \mathrm{PZ}$ \\
\hline
\end{tabular}


Table 1. Cont.

\begin{tabular}{|c|c|c|c|c|c|c|c|}
\hline Year & Author & Study Design & Disease & $\begin{array}{l}\text { Patients } \\
\text { (n) }\end{array}$ & $\begin{array}{c}\text { ONJ } \\
\text { Cases }\end{array}$ & $\begin{array}{l}\text { Prevalence } \\
(\%)\end{array}$ & Used Agent \\
\hline \multirow{16}{*}{2008} & Boonyapakorn [36] & pros & mult myel & 58 & 10 & 17.24 & $\mathrm{P}, \mathrm{PZ}, \mathrm{IZ}, \mathrm{Z}$ \\
\hline & Fehm [37] & retro & breast ca & 233 & 10 & 4.29 & $\mathrm{Z}, \mathrm{ICPZ}$ \\
\hline & \multirow{2}{*}{ Ibrahim [38] } & retro & breast ca & 220 & 5 & 2.27 & $\mathrm{PZ}, \mathrm{Z}$ \\
\hline & & retro & mult myel & 59 & 2 & 3.39 & $\mathrm{PZ}, \mathrm{Z}$ \\
\hline & Walter [39] & css & prostate ca & 43 & 8 & 18.6 & $\mathrm{IZ}, \mathrm{PZ}, \mathrm{Z}$ \\
\hline & Yonemori [40] & prosp & breast ca & 18 & 0 & 0 & D \\
\hline & Ellis [41] & prosp & breast ca & 106 & 0 & 0 & $\mathrm{D}$ \\
\hline & \multirow{2}{*}{ Christodoulou [42] } & retro & breast ca & 75 & 2 & 2.67 & $\mathrm{Z}, \mathrm{I}$ \\
\hline & & retro & prostate ca & 11 & 1 & 9.1 & $\mathrm{Z}, \mathrm{I}$ \\
\hline & \multirow{3}{*}{ Estilo [43] } & retro & breast ca & 134 & 18 & 13.43 & $\mathrm{P}, \mathrm{Z}, \mathrm{PZ}$ \\
\hline & & retro & prostate ca & 31 & 4 & 12.9 & $\mathrm{P}, \mathrm{Z}, \mathrm{PZ}$ \\
\hline & & retro & mult myel & 145 & 6 & 4.14 & $\mathrm{P}, \mathrm{Z}, \mathrm{PZ}$ \\
\hline & \multirow{2}{*}{ Hoff [14] } & retro & breast ca & 1338 & 16 & 1.2 & $\mathrm{P}, \mathrm{Z}$ \\
\hline & & retro & mult myel & 548 & 13 & $2 . .37$ & $\mathrm{P}, \mathrm{Z}$ \\
\hline & Montefusco [44] & retro & mult myel & 178 & 9 & 5.06 & $\mathrm{BP}$ \\
\hline & Musto [45] & prosp & mult myel & 81 & 1 & 1.23 & $\mathrm{Z}$ \\
\hline \multirow{20}{*}{2009} & Walter [46] & css & breast ca & 75 & 4 & 5.33 & Z, PZI \\
\hline & Aragon-Ching [47] & pros & prostate ca & 60 & 11 & 18.33 & $\mathrm{Z}$ \\
\hline & Cetiner [48] & pros & mult myel & 32 & 5 & 15.63 & Z \\
\hline & Crawford [49] & retro & breast ca & 113 & 10 & 3.5 & $\mathrm{P}, \mathrm{PZ}, \mathrm{Z}$ \\
\hline & Dimopoulos [50] & pros & mult myel & 128 & 16 & 12.5 & Z \\
\hline & Haidar [51] & retro & prostate ca & 51 & 2 & 3.92 & $\mathrm{Z}$ \\
\hline & \multirow{2}{*}{ Ripamonti [52] } & retro & breast ca & 590 & 18 & 3.05 & $\mathrm{P}, \mathrm{PZ}, \mathrm{Z}$ \\
\hline & & prosp & breast ca & 112 & 2 & 1.79 & $\mathrm{P}, \mathrm{PZ}, \mathrm{Z}$ \\
\hline & \multirow{3}{*}{ Vahtsevanos [53] } & retro & breast ca & 1041 & 32 & 3.07 & Z, P, I, PZ, IZ \\
\hline & & retro & mult myel & 539 & 46 & 8.53 & $\mathrm{P}, \mathrm{PZ}, \mathrm{Z}$ \\
\hline & & retro & prostate ca & 41 & 2 & 4.88 & $\mathrm{P}, \mathrm{Z}, \mathrm{ZI}$ \\
\hline & \multirow{4}{*}{ Fizazi [54] } & prosp & prostate & 17 & 0 & 0 & $\mathrm{P}, \mathrm{Z}$ \\
\hline & & prosp & breast ca & 16 & 0 & 0 & $\mathrm{P}, \mathrm{Z}$ \\
\hline & & prosp & prostate ca & 33 & 0 & 0 & $\mathrm{D}$ \\
\hline & & prosp & breast ca & 30 & 0 & 0 & $\mathrm{D}$ \\
\hline & \multirow{2}{*}{ Bonomi [55] } & retro & breast ca & 238 & 7 & 2.94 & $\mathrm{P}, \mathrm{PZ}, \mathrm{Z}$ \\
\hline & & retro & protate ca & 46 & 1 & 2.17 & $\mathrm{P}, \mathrm{PZ}, \mathrm{Z}$ \\
\hline & \multirow{3}{*}{ Stumpe [56] } & retro & mult myel & 128 & 3 & 2.34 & $\mathrm{P}, \mathrm{Z}, \mathrm{PZ}$ \\
\hline & & retro & breast ca & 241 & 1 & 0.41 & $\mathrm{P}, \mathrm{Z}, \mathrm{PZ}$ \\
\hline & & retro & prostate ca & 128 & 1 & 0.78 & $\mathrm{P}, \mathrm{Z}, \mathrm{PZ}$ \\
\hline \multirow{8}{*}{2010} & \multirow{2}{*}{ Walter [16] } & retro & mult myel & 81 & 4 & 4.94 & $\mathrm{U}, \mathrm{PZ}$ \\
\hline & & css & mult myel & 78 & 16 & 20.51 & Z, PZ, IZ, PZI \\
\hline & Bantis [11] & retro & prostate ca & 60 & 9 & 15 & $\mathrm{Z}$ \\
\hline & \multirow{2}{*}{ Gimsing [57] } & retro & breast ca & 250 & 8 & 3.2 & P normal dose (90 mg) \\
\hline & & retro & breast ca & 252 & 2 & 0.79 & P low dose $(30 \mathrm{mg})$ \\
\hline & Pakovic [58] & retro & mult myel & 190 & 2 & 1.05 & P, PI, I \\
\hline & \multirow{2}{*}{ Stopeck [59] } & prosp & breast ca & 1020 & 20 & 1.96 & $\mathrm{D}$ \\
\hline & & prosp & breast ca & 1013 & 14 & 1.38 & $\mathrm{Z}$ \\
\hline \multirow{3}{*}{2011} & Fi:nai $[601$ & prosp & prostate ca & 950 & 22 & 2.32 & $\mathrm{D}$ \\
\hline & Fizazi [60] & prosp & prostate ca & 951 & 12 & 1.26 & $\mathrm{Z}$ \\
\hline & Quispe [61] & retro & breast ca & 110 & 10 & 9.09 & $\mathrm{Z}$ \\
\hline & Ding [62] & retro & breast ca & 181 & 1 & 0.55 & $\mathrm{P}, \mathrm{I}, \mathrm{Z}$ \\
\hline & Miyazaki [63] & retro & prostate ca & 111 & 9 & 8.11 & Z \\
\hline & Smith [64] & prosp & prostate ca & 716 & 33 & 4.61 & $\mathrm{D}$ \\
\hline & & retro & breast ca & 190 & 8 & 4.21 & $\mathrm{P}, \mathrm{PZ}, \mathrm{Z}$ \\
\hline 2012 & Thumbigere-Math [65] & retro & mult myel & 83 & 6 & 7.23 & $\mathrm{P}, \mathrm{PZ}, \mathrm{Z}$ \\
\hline & & retro & prostate ca & 84 & 2 & 2.38 & $\mathrm{P}, \mathrm{PZ}, \mathrm{Z}$ \\
\hline & Rugani [66] & retro & breast ca & 48 & 5 & 10.42 & $\mathrm{Z}$ \\
\hline & Then [67] & retro & mult myel & 120 & 23 & 19.17 & $\mathrm{P}, \mathrm{Z}, \mathrm{I}$ \\
\hline & Martin [68] & prosp & breast ca & 1026 & 0 & 0 & $\mathrm{D}$ \\
\hline & Henry [69] + Saad [70] & prosp & mult myel & 180 & 6 & 3.33 & $\mathrm{D}, \mathrm{Z}$ \\
\hline
\end{tabular}


Table 1. Cont.

\begin{tabular}{|c|c|c|c|c|c|c|c|}
\hline Year & Author & Study Design & Disease & $\begin{array}{l}\text { Patients } \\
\text { (n) }\end{array}$ & $\begin{array}{l}\text { ONJ } \\
\text { Cases }\end{array}$ & $\begin{array}{c}\text { Prevalence } \\
(\%)\end{array}$ & Used Agent \\
\hline \multirow{5}{*}{2013} & \multirow{2}{*}{ Assaf [71] } & retro & breast ca & 95 & 9 & 9.47 & P, I, Z, ZI, PI \\
\hline & & retro & mult myel & 42 & 5 & 11.9 & P, I, Z, ZI, PI \\
\hline & Coleman [72] & prosp & breast ca & 1065 & 5 & 0.47 & $\mathrm{Z}$ \\
\hline & \multirow{2}{*}{ Brufsky [73] } & retro & breast ca & 159 & 6 & 3.77 & $\mathrm{P}, \mathrm{Z}, \mathrm{PZ}$ \\
\hline & & retro & breast ca & 62 & 1 & 1.61 & $\mathrm{P}, \mathrm{Z}, \mathrm{PZ}$ \\
\hline \multirow{5}{*}{2014} & Rathbone [74] & prosp & breast ca & 1681 & 26 & 1.55 & $Z$ \\
\hline & Barrett-Lee [75] & prosp & breast ca & 697 & 9 & 1.29 & $\mathrm{Z}$ \\
\hline & Coleman [76] & prosp & breast ca & 1685 & 26 & 1.54 & Z \\
\hline & Jackson [77] & prosp & mult myel & 981 & 36 & 3.67 & Z \\
\hline & Gnant [78] & prosp & breast ca & 900 & 0 & 0 & $\mathrm{Z}$ \\
\hline \multirow{4}{*}{2015} & \multirow{3}{*}{ Vidal-Real [79] } & retro & prostate ca & 43 & 9 & 20.93 & $\mathrm{Z}$ \\
\hline & & retro & breast ca & 15 & 4 & 26.67 & Z \\
\hline & & retro & mult myel & 18 & 0 & 0 & Z \\
\hline & Rodrigues [80] & prosp & prostate ca & 324 & 2 & 0.62 & Z \\
\hline \multirow{4}{*}{2016} & \multirow{4}{*}{ Stopeck [81] } & prosp & breast ca & 318 & 20 & 6.29 & $\mathrm{D}$ \\
\hline & & prosp & breast ca & 334 & 18 & 5.39 & ZD \\
\hline & & prosp & prostate ca & 147 & 12 & 8.16 & $\mathrm{D}$ \\
\hline & & prosp & prostate ca & 118 & 7 & 5.93 & ZD \\
\hline
\end{tabular}

Abbreviations: prosp (prospective), retro (retrospective), ccs (cross-sectional study), ? (unknown), ca (cancer), mult myel (multiple myeloma), Z (zoldronate), P (pamidonate), I (ibandronate), D (denosumab).

Table 2. Weighted prevalences in breast cancer, prostate cancer, and multiple myeloma patients.

\begin{tabular}{ccccccccccccc}
\hline & \multicolumn{3}{c}{ Breast Cancer } & \multicolumn{3}{c}{ Prostate Cancer } & \multicolumn{3}{c}{ Multiple Myeloma } & \multicolumn{3}{c}{ Total } \\
\cline { 2 - 13 } & $\mathbf{n}$ & Cases & prev & n & Cases & prev & n & Cases & prev & n & Cases & prev \\
\hline-2009 & 5531 & 156 & $2.82 \%$ & 732 & 44 & $6.01 \%$ & 6796 & 344 & $5.06 \%$ & 13,059 & 544 & $4.17 \%$ \\
$2010+$ & 11,101 & 192 & $1.73 \%$ & 3504 & 117 & $3.34 \%$ & 1773 & 98 & $5.53 \%$ & 16,378 & 407 & $2.49 \%$ \\
Total & 16,632 & 348 & $2.09 \%$ & 4236 & 161 & $3.80 \%$ & 8569 & 442 & $5.16 \%$ & 29,437 & 951 & $3.23 \%$ \\
\hline
\end{tabular}

Abbreviations: $\mathrm{n}$ (number of patients); prev (prevalence); Cases (number of patients with ONJ).

Published prevalences in patients with breast cancer range from 0 to $26.7 \%$ (median $2.6 \%$ ), from 0 to $20.9 \%$ (median $4.8 \%$ ) in prostate cancer patients, and from 0 to $20.5 \%$ (median $5.1 \%$ ) in patients with multiple myeloma (Figure 1).

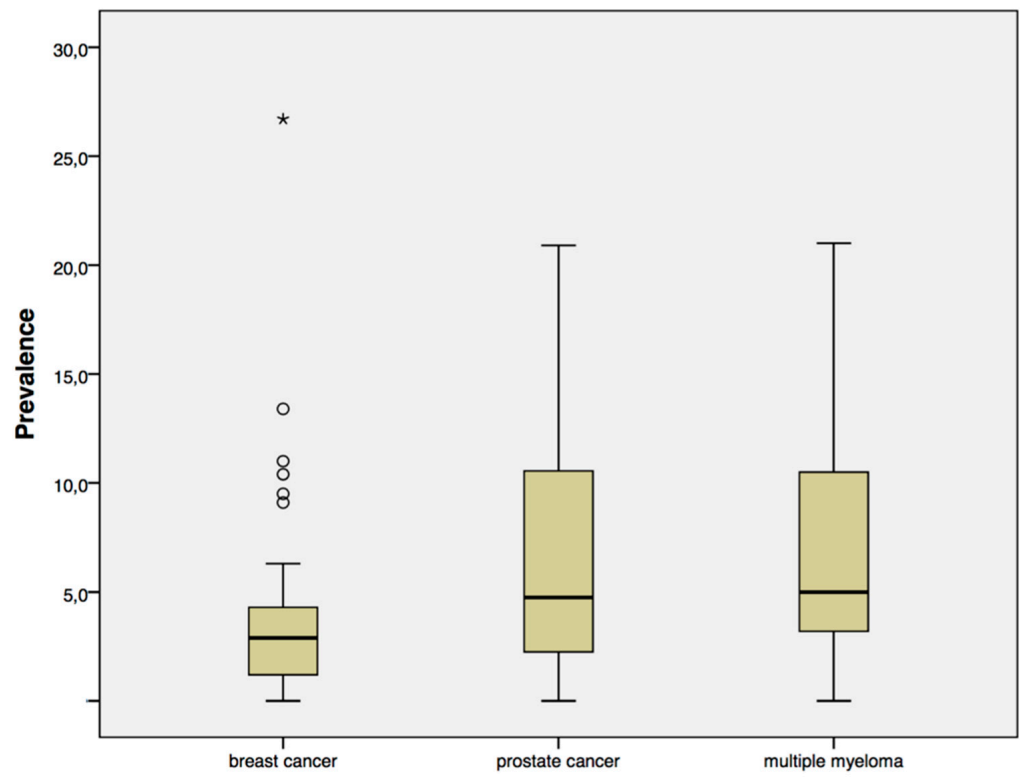

Figure 1. Published prevalences. 
Overall prevalence in all patients published until 2009 ranges from 0 to $18.6 \%$ (median $3.6 \%$ ) and from 0 to $26.7 \%$ (median $3.7 \%$ ) in papers published since 2010 (Figure 2).

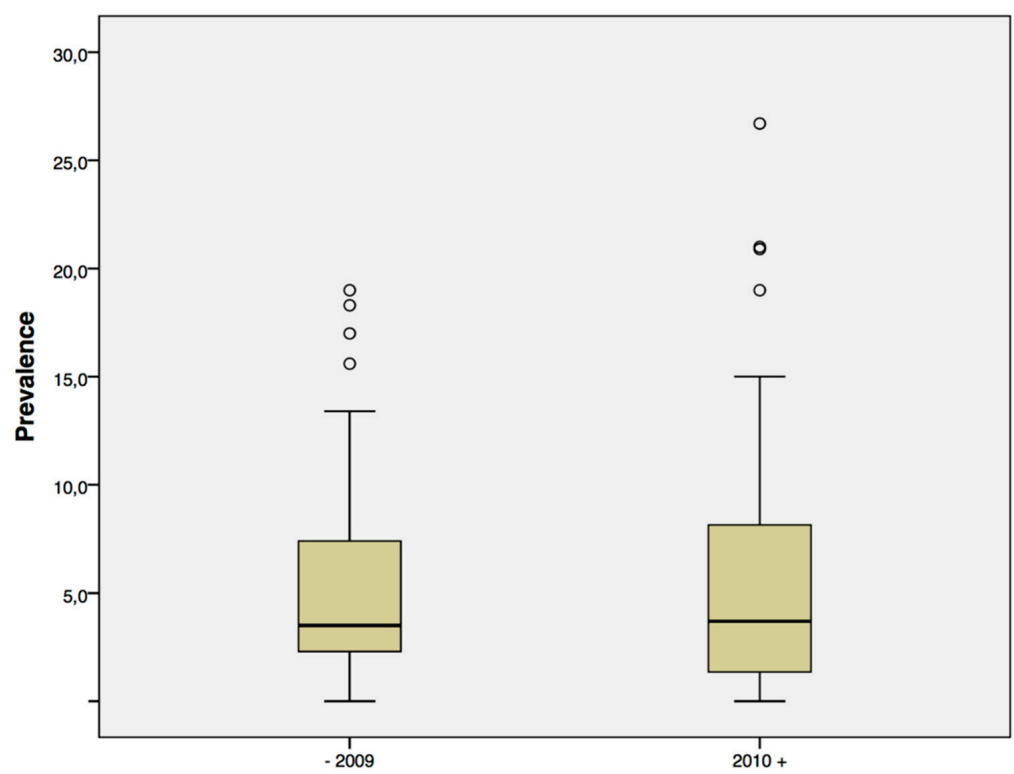

Figure 2. Published prevalences in reports until 2009 and since 2010.

\section{Discussion}

In this paper we determined the weighted prevalence of medication-related osteonecrosis of the jaw in patients with breast cancer, prostate cancer, and multiple myeloma, including 69 reports comprising 29,670 patients. Prevalence was $2.09 \%$ in the breast cancer group, $3.8 \%$ in the prostate cancer group, and $5.16 \%$ for multiple myeloma patients.

To the best of our knowledge there are three further reports addressing this issue. In 2009 Walter et al. [46] provided an overview including 25 studies from 2005 to 2008 comprising 5825 patients and reported on lower prevalences in breast cancer patients compared to prostate cancer and multiple myeloma patients. In 2010 Walter et al. [16] also addressed the problem of possible under-reporting of MRONJ cases if dental examinations are left out. In 2014 Boquete-Castro et al. published a systemic analysis evaluating the adverse advents of Denosumab [82]. They found seven articles reporting on $97 \mathrm{MRONJ}$ cases. Incidences were low and ranged between 0 and $2 \%$, but exceeded the incidences in the zoledronate control group. Published prevalences of medication-related osteonecrosis of the jaw show a great range. Possible explanations have been discussed in the literature and may include variations in sample size, varying methods of data assessment/analysis, and limitations due to voluntary case reporting [65]. Furthermore, when evaluating the published literature we had to realize that in most papers MRONJ definition is not clearly stated. Very often descriptions are not detailed and do not refer to a specific classification system, or are even left out completely.

Despite this inhomogeneity it has been shown that the application of zoledronic acid produces a greater risk than the use of pamidronate or the combination of zoledronate and pamidronate [25]. Additionally, $\mathrm{ONJ}$ onset seems to be earlier among patients receiving zoledronic acid as compared to patients receiving pamidronate [18], and even later if alendronate or risedronate is used [25,83,84].

Regarding denosumab, ONJ prevalence was slightly higher compared with zoledronate, but no significant difference was found [70].

In general, ONJ develops more frequently if parenteral administration of antiresorptive agents are used [85-87] and significantly correlates with the number of applied doses [12,53,65]. Differences in applied dosing protocols may also be the reason for the discrepancy of ONJ prevalences in patients 
with different primary diseases, resulting in a higher risk for patients suffering from multiple myeloma (weighted ONJ-prevalence 5.16\%) compared to patients with breast cancer (weighted ONJ prevalence 2.09\%).

Beyond that several additional factors influencing the risk of MRONJ have been identified.

Concomitant oral disease, respectively, oral inflammation, may increase the risk of ONJ [14,67], as well as wearing of dentures [47] and anatomical circumstances. ONJ occurs more frequently in the mandible with described predilection for the molar and premolar region, as well as regions with thin mucosal coverage, like tori or the mylohyoid line $[70,87,88]$.

Oral surgery, and above all, dental extractions, are most frequently named to increase ONJ risk around seven- to more than ten-fold [14,20,53,70,89].

Taylor et al., who reviewed the clinical records of 225 patients at risk who underwent dental extraction, identified eight $\mathrm{ONJ}$ cases out of $23(34.8 \%)$ patients prescribed intravenous bisphosphonates and five ONJ cases in 202 patients (2.5\%) with oral bisphosphonate administration [90]. However, the periodontal and inflammation status in the surrounding bone might be a more important factor in the development of osteonecrosis rather than the procedure of the extraction itself [91].

In addition, systemic risk factors have been described. ONJ onset seems to be more frequent in women and in advanced age $[17,86-88]$. This might be attributed to the fact that important primary diseases, like breast cancer and osteoporosis, are more frequent in women, respectively, and that cancer and osteoporosis commonly develop with increasing age. Regarding the group of multiple myeloma patients, no difference in gender could be detected $[20,25,50,87]$.

Furthermore, the wearing of removable mucosa-retained dentures also becomes more likely with increasing age and is a known risk factor. Patients with removable dentures are more likely to develop osteonecrosis compared to patients with fixed partial dentures and patients without substitution of potentially messing teeth [92].

Concomitant medical therapy may enhance ONJ risk, which has been particularly reported for corticosteroids and antiangiogenic therapy. A correlation to chemotherapy, diabetes, or anaemia is less substantiated $[12,20,25,70]$, although a recently published article sees an association to a pathological glucose metabolism [93]. Altogether, systemic risk factors seem to have less impact than local variables [70].

Finally, differences in diagnostic criteria, mainly resulting from differences or alterations in classification guidelines, may also have an impact, albeit we could not detect a difference in published prevalences until 2009 compared to those since 2010, after the revision of AAOMS guidelines. It could be hypothesized that intensifying oral inspections to detect early forms (Stage 0 ) and possibly including patients presenting sinus tracts into verified ONJ cases, resulted in a higher prevalence as already demonstrated [63]. However, this effect might be compensated by the greater awareness towards ONJ risk and, consequently, the implementation of preventive measures. Routine dental prevention to eliminate potential sites of infection prior to antiresorptive treatment and managing risk factors in patients at risk reduces the BRONJ rate, as already described in the literature $[12,50,52,94,95]$. Furthermore, it has been reported that dental extraction and oral surgery are quite safe if certain rules are obeyed $[13,15,96,97]$.

\section{Conclusions}

The exact pathogenic mechanisms of MRONJ development are still unknown, but risk factors have been described. Patients with malignant diseases carry a relevant risk for MRONJ. It has been shown that it is possible to reduce ONJ risk by implementation of routine dental preventive measures and management of known risk factors. Consequently, a close cooperation between medical specialties involved in the treatment of malignoma and multiple myeloma patients at risk is crucial to minimize ONJ prevalence.

Acknowledgments: Statistical evaluation performed by Clemens Keil, Clemens.keil@medunigraz.at.

Conflicts of Interest: The authors declare no conflict of interest. 


\section{References}

1. Marx, R.E. Pamidronate (Aredia) and zoledronate (Zometa) induced avascular necrosis of the jaws: A growing epidemic. J. Oral Maxillofac. Surg. 2003, 61, 1115-1117. [CrossRef]

2. Tarassoff, P.; Csermak, K. Avascular necrosis of the jaws: Risk factors in metastatic cancer patients. J. Oral Maxillofac. Surg. 2003, 61, 1238-1239. [CrossRef] [PubMed]

3. Ruggiero, S.L.; Dodson, T.B.; Assael, L.A.; Landesberg, R.; Marx, R.E.; Mehrotra, B.; American Association of Oral and Maxillofacial Surgeons. American Association of Oral and Maxillofacial Surgeons position paper on bisphosphonate-related osteonecrosis of the jaws-2009 update. J. Oral Maxillofac. Surg. 2009, 67, S2-S12.

4. Ziebart, T.; Pabst, A.; Klein, M.O.; Kammerer, P.; Gauss, L.; Brullmann, D.; Al-Nawas, B.; Walter, C. Bisphosphonates: Restrictions for vasculogenesis and angiogenesis: Inhibition of cell function of endothelial progenitor cells and mature endothelial cells in vitro. Clin. Oral Investig. 2011, 15, 105-111. [CrossRef] [PubMed]

5. Hoefert, S.; Schmitz, I.; Tannapfel, A.; Eufinger, H. Importance of microcracks in etiology of bisphosphonate-related osteonecrosis of the jaw: A possible pathogenetic model of symptomatic and non-symptomatic osteonecrosis of the jaw based on scanning electron microscopy findings. Clin. Oral Investig. 2010, 14, 271-284. [CrossRef] [PubMed]

6. Rustemeyer, J.; Bremerich, A. Bisphosphonate-associated osteonecrosis of the jaw: What do we currently know? A survey of knowledge given in the recent literature. Clin. Oral Investig. 2010, 14, 59-64. [CrossRef] [PubMed]

7. Allen, M.R.; Burr, D.B. The pathogenesis of bisphosphonate-related osteonecrosis of the jaw: So many hypotheses, so few data. J. Oral Maxillofac. Surg. 2009, 67, S61-S70. [CrossRef] [PubMed]

8. Advisory Task Force on Bisphosphonate-Related Ostenonecrosis of the Jaws; American Association of Oral and Maxillofacial Surgeons. American Association of Oral and Maxillofacial Surgeons position paper on bisphosphonate-related osteonecrosis of the jaws. J. Oral Maxillofac. Surg. 2007, 65, 369-376.

9. Fedele, S.; Porter, S.R.; D’Aiuto, F.; Aljohani, S.; Vescovi, P.; Manfredi, M.; Arduino, P.G.; Broccoletti, R.; Musciotto, A.; Di Fede, O.; et al. Nonexposed variant of bisphosphonate-associated osteonecrosis of the jaw: A case series. Am. J. Med. 2010, 123, 1060-1064. [CrossRef] [PubMed]

10. Almăşan, H.A.; Băciut, M.; Rotaru, H.; Bran, S.; Almăşan, O.C.; Băciut, G. Osteonecrosis of the jaws associated with the use of bisphosphonates. Discussion over 52 cases. Rom. J. Morphol. Embryol. 2011, 52, 1233-1241. [PubMed]

11. Bantis, A.; Zissimopoulos, A.; Sountoulides, P.; Kalaitzis, C.; Giannakopoulos, S.; Deftereos, S.; Tsakaldimis, G.; Thomaidis, V.; Touloupidis, S. Bisphosphonate-induced osteonecrosis of the jaw in patients with bone metastatic, hormone-sensitive prostate cancer. Risk factors and prevention strategies. Tumori 2011, 97, 479-483. [PubMed]

12. Bonacina, R.; Mariani, U.; Villa, F.; Villa, A. Preventive strategies and clinical implications for bisphosphonate-related osteonecrosis of the jaw: A review of 282 patients. J. Can. Dent. Assoc. 2011, 77, b147. [PubMed]

13. Schubert, M.; Klatte, I.; Linek, W.; Müller, B.; Döring, K.; Eckelt, U.; Hemprich, A.; Berger, U.; Hendricks, J. The Saxon Bisphosphonate Register-Therapy and prevention of bisphosphonate-related osteonecrosis of the jaws. Oral Oncol. 2011, 48, 349-354. [CrossRef] [PubMed]

14. Hoff, A.O.; Toth, B.B.; Altundag, K.; Johnson, M.M.; Warneke, C.L.; Hu, M.; Nooka, A.; Sayegh, G.; Guarneri, V.; Desrouleaux, K.; et al. Frequency and risk factors associated with osteonecrosis of the jaw in cancer patients treated with intravenous bisphosphonates. J. Bone Miner. Res. 2008, 23, 826-836. [CrossRef] [PubMed]

15. Mavrokokki, T.; Cheng, A.; Stein, B.; Goss, A. Nature and frequency of bisphosphonate-associated osteonecrosis of the jaws in Australia. J. Oral Maxillofac. Surg. 2007, 65, 415-423. [CrossRef] [PubMed]

16. Walter, C.; Al-Nawas, B.; Frickhofen, N.; Gamm, H.; Beck, J.; Reinsch, L.; Blum, C.; Grötz, K.A.; Wagner, W. Prevalence of bisphosphonate associate osteonecrosis of the jaws in multiple myeloma patients. Head Face Med. 2010, 6, 11. [CrossRef] [PubMed]

17. Bamias, A.; Kastritis, E.; Bamia, C.; Moulopoulos, L.A.; Melakopoulos, I.; Bozas, G.; Koutsoukou, V.; Gika, D.; Anagnostopoulos, A.; Papadimitriou, C.; et al. Osteonecrosis of the jaw in cancer after treatment with bisphosphonates: Incidence and risk factors. J. Clin. Oncol. 2005, 23, 8580-8587. [CrossRef] [PubMed] 
18. Durie, B.G.; Katz, M.; Crowley, J. Osteonecrosis of the jaw and bisphosphonates. N. Engl. J. Med. 2005, 353, 99-102. [PubMed]

19. Guarneri, V.; Donati, S.; Nicolini, M.; Giovannelli, S.; D'Amico, R.; Conte, P.F. Renal safety and efficacy of i.v. bisphosphonates in patients with skeletal metastases treated for up to 10 Years. Oncologist 2005, 10, 842-848. [CrossRef] [PubMed]

20. Badros, A.; Weikel, D.; Salama, A.; Goloubeva, O.; Schneider, A.; Rapoport, A.; Fenton, R.; Gahres, N.; Sausville, E.; Ord, R.; et al. Osteonecrosis of the jaw in multiple myeloma patients: Clinical features and risk factors. J. Clin. Oncol. 2006, 24, 945-952. [CrossRef] [PubMed]

21. Calvo-Villas, J.M.; Tapia Torres, M.; Govantes Rodríguez, J.; Carreter de Granda, E.; Sicilia Guillén, F. Osteonecrosis of the jaw in patients with multiple myeloma during and after treatment with zoledronic acid. Med. Clin. 2006, 127, 576-579. [CrossRef]

22. Dimopoulos, M.A.; Kastritis, E.; Anagnostopoulos, A.; Melakopoulos, I.; Gika, D.; Moulopoulos, L.A.; Bamia, C.; Terpos, E.; Tsionos, K.; Bamias, A. Osteonecrosis of the jaw in patients with multiple myeloma treated with bisphosphonates: Evidence of increased risk after treatment with zoledronic acid. Haematologica 2006, 91, 968-971. [PubMed]

23. Sanna, G.; Preda, L.; Bruschini, R.; Cossu Rocca, M.; Ferretti, S.; Adamoli, L.; Verri, E.; Franceschelli, L.; Goldhirsch, A.; Nole, F. Bisphosphonates and jaw osteonecrosis in patients with advanced breast cancer. Ann. Oncol. 2006, 17, 1512-1516. [CrossRef] [PubMed]

24. Tosi, P.; Zamagni, E.; Cangini, D.; Tacchetti, P.; Di Raimondo, F.; Catalano, L.; D'Arco, A.; Ronconi, S.; Cellini, C.; Offidani, M.; et al. Osteonecrosis of the jaws in newly diagnosed multiple myeloma patients treated with zoledronic acid and thalidomide-dexamethasone. Blood 2006, 108, 3951-3952. [CrossRef] [PubMed]

25. Zervas, K.; Verrou, E.; Teleioudis, Z.; Vahtsevanos, K.; Banti, A.; Mihou, D.; Krikelis, D.; Terpos, E. Incidence, risk factors and management of osteonecrosis of the jaw in patients with multiple myeloma: A single-centre experience in303patients. Br. J. Haematol. 2006, 134, 620-623. [CrossRef] [PubMed]

26. Ortega, C.; Faggiuolo, R.; Vormola, R.; Montemurro, F.; Nanni, D.; Goia, F.; Aglietta, M. Jaw complications in breast and prostate cancer patients treated with zoledronic acid. Acta Oncol. 2006, 45, 216-217. [CrossRef] [PubMed]

27. Aguiar Bujanda, D.; Bohn Sarmiento, U.; Cabrera Suarez, M.A.; Aguiar Morales, J. Assessment of renal toxicity and osteonecrosis of the jaws in patients receiving zoledronic acid for bone metastasis. Ann. Oncol. 2007, 18, 556-560. [CrossRef] [PubMed]

28. Corso, A.; Varettoni, M.; Zappasodi, P.; Klersy, C.; Mangiacavalli, S.; Pica, G.; Lazzarino, M. A different schedule of zoledronic acid can reduce the risk of the osteonecrosis of the jaw in patients with multiple myeloma. Leukemia 2007, 21, 1545-1548. [CrossRef] [PubMed]

29. Garcia Saenz, J.A.; Lopez Tarruella, S.; Garcia Paredes, B.; Rodriguez Lajusticia, L.; Villalobos, L.; Diaz Rubio, E. Osteonecrosis of the jaw as an adverse bisphosphonate event: Three cases of bone metastatic prostate cancer patients treated with zoledronic acid. Med. Oral Patol. Oral Cir. Bucal 2007, 12, E351-E356. [PubMed]

30. Jadu, F.; Lee, L.; Pharoah, M.; Reece, D.; Wang, L. A retrospective study assessing the incidence, risk factors and comorbidities of pamidronate-related necrosis of the jaws in multiple myeloma patients. Ann. Oncol. 2007, 18, 2015-2019. [CrossRef] [PubMed]

31. Ortega, C.; Montemurro, F.; Faggiuolo, R.; Vormola, R.; Nanni, D.; Goia, F.; Gilardino, M.O.; Aglietta, M. Osteonecrosis of the jaw in prostate cancer patients with bone metastases treated with zoledronate: A retrospective analysis. Acta Oncol. 2007, 46, 664-668. [CrossRef] [PubMed]

32. Petrucci, M.T.; Gallucci, C.; Agrillo, A.; Mustazza, M.C.; Foa, R. Role of ozone therapy in the treatment of osteonecrosis of the jaws in multiple myeloma patients. Haematologica 2007, 92, 1289-1290. [CrossRef] [PubMed]

33. Wang, E.P.; Kaban, L.B.; Strewler, G.J.; Raje, N.; Troulis, M.J. Incidence of osteonecrosis of the jaw in patients with multiple myeloma and breast or prostate cancer on intravenous bisphosphonate therapy. J. Oral Maxillofac. Surg. 2007, 65, 1328-1331. [CrossRef] [PubMed]

34. Lipton, A.; Steger, G.G.; Figueroa, J.; Alvarado, C.; Solal-Celigny, P.; Body, J.J.; de Boer, R.; Berardi, R.; Gascon, P.; Tonkin, K.S.; et al. Randomized active-controlled phase II study of denosumab efficacy and safety in patients with breast cancer-related bone metastases. J. Clin. Oncol. 2007, 25, 4431-4437. [CrossRef] [PubMed] 
35. Pozzi, S.; Marcheselli, R.; Sacchi, S.; Baldini, L.; Angrilli, F.; Pennese, E.; Quarta, G.; Stelitano, C.; Caparotti, G.; Luminari, S.; et al. Bisphosphonate-associated osteonecrosis of the jaw: A review of 35 cases and an evaluation of its frequency in multiple myeloma patients. Leuk. Lymphoma 2007, 48, 56-64. [CrossRef] [PubMed]

36. Boonyapakorn, T.; Schirmer, I.; Reichart, P.A.; Sturm, I.; Massenkeil, G. Bisphosphonate-induced osteonecrosis of the jaws: Prospective study of 80 patients with multiple myeloma and other malignancies. Oral Oncol. 2008, 44, 857-869. [CrossRef] [PubMed]

37. Fehm, T.; Beck, V.; Banys, M.; Lipp, H.P.; Hairass, M.; Reinert, S.; Solomayer, E.F.; Wallwiener, D.; Krimmel, M. Bisphosphonate-induced osteonecrosis of the jaw (ONJ): Incidence and risk factors in patients with breast cancer and gynecological malignancies. Gynecol. Oncol. 2009, 112, 605-609. [CrossRef] [PubMed]

38. Ibrahim, T.; Barbanti, F.; Giorgio-Marrano, G.; Mercatali, L.; Ronconi, S.; Vicini, C.; Amadori, D. Osteonecrosis of the jaw in patients with bone metastases treated with bisphosphonates: A retrospective study. Oncologist 2008, 13, 330-336. [CrossRef] [PubMed]

39. Walter, C.; Al-Nawas, B.; Grotz, K.A.; Thomas, C.; Thuroff, J.W.; Zinser, V.; Gamm, H.; Beck, J.; Wagner, W. Prevalence and risk factors of bisphosphonate-associated osteonecrosis of the jaw in prostate cancer patients with advanced disease treated with zoledronate. Eur. Urol. 2008, 54, 1066-1072. [CrossRef] [PubMed]

40. Yonemori, K.; Fujiwara, Y.; Minami, H.; Kitagawa, K.; Fujii, H.; Arai, T.; Sohn, W.; Ohkura, M.; Ohtsu, T. Phase 1 trial of denosumab safety, pharmacokinetics, and pharmacodynamics in Japanese women with breast cancer-related bone metastases. Cancer Sci. 2008, 99, 1237-1242. [CrossRef] [PubMed]

41. Ellis, G.K.; Bone, H.G.; Chlebowski, R.; Paul, D.; Spadafora, S.; Smith, J.; Fan, M.; Jun, S. Randomized trial of denosumab in patients receiving adjuvant aromatase inhibitors for nonmetastatic breast cancer. J. Clin. Oncol. 2008, 26, 4875-4882. [CrossRef] [PubMed]

42. Christodoulou, C.; Pervena, A.; Klouvas, G.; Galani, E.; Falagas, M.E.; Tsakalos, G.; Visvikis, A.; Nikolakopoulou, A.; Acholos, V.; Karapanagiotidis, G.; et al. Combination of bisphosphonates and antiangiogenic factors induces osteonecrosis of the jaw more frequently than bisphosphonates alone. Oncology 2009, 76, 209-211. [CrossRef] [PubMed]

43. Estilo, C.L.; Van Poznak, C.H.; Wiliams, T.; Bohle, G.C.; Lwin, P.T.; Zhou, Q.; Riedel, E.R.; Carlson, D.L.; Schoder, H.; Farooki, A.; et al. Osteonecrosis of the maxilla and mandible in patients with advanced cancer treated with bisphosphonate therapy. Oncologist 2008, 13, 911-920. [CrossRef] [PubMed]

44. Montefusco, V.; Gay, F.; Spina, F.; Miceli, R.; Maniezzo, M.; Teresa Ambrosini, M.; Farina, L.; Piva, S.; Palumbo, A.; Boccadoro, M.; et al. Antibiotic prophylaxis before dental procedures may reduce the incidence of osteonecrosis of the jaw in patients with multiple myeloma treated with bisphosphonates. Leuk. Lymphoma 2008, 49, 2156-2162. [CrossRef] [PubMed]

45. Musto, P.; Petrucci, M.T.; Bringhen, S.; Guglielmelli, T.; Caravita, T.; Bongarzoni, V.; Andriani, A.; D'Arena, G.; Balleari, E.; Pietrantuono, G.; et al. A multicenter, randomized clinical trial comparing zoledronic acid versus observation in patients with asymptomatic myeloma. Cancer 2008, 113, 1588-1595. [CrossRef] [PubMed]

46. Walter, C.; Al-Nawas, B.; Du Bois, A.; Buch, L.; Harter, P.; Grötz, K.A. Incidence of bisphosphonate-associated osteonecrosis of the jaws in breast cancer patients. Cancer 2009, 115, 1631-1637. [CrossRef] [PubMed]

47. Aragon-Ching, J.B.; Ning, Y.M.; Chen, C.C.; Latham, L.; Guadagnini, J.P.; Gulley, J.L.; Arlen, P.M.; Wright, J.J.; Parnes, H.; Figg, W.D.; et al. Higher incidence of Osteonecrosis of the Jaw (ONJ) in patients with metastatic castration resistant prostate cancer treated with anti-angiogenic agents. Cancer Investig. 2009, 27, 221-226. [CrossRef] [PubMed]

48. Cetiner, S.; Sucak, G.T.; Kahraman, S.A.; Aki, S.Z.; Kocakahyaoglu, B.; Gultekin, S.E.; Cetiner, M.; Haznedar, R. Osteonecrosis of the jaw in patients with multiple myeloma treated with zoledronic acid. J. Bone Miner. Metab. 2009, 27, 435-443. [CrossRef] [PubMed]

49. Crawford, B.S.; McNulty, R.M.; Kraut, E.H.; Turowski, R.C. Extended use of intravenous bisphosphonate therapy for the prevention of skeletal complications in patients with cancer. Cancer Investig. 2009, 27, 984-988. [CrossRef] [PubMed]

50. Dimopoulos, M.A.; Kastritis, E.; Bamia, C.; Melakopoulos, I.; Gika, D.; Roussou, M.; Migkou, M.; Eleftherakis-Papaiakovou, E.; Christoulas, D.; Terpos, E.; et al. Reduction of osteonecrosis of the jaw (ONJ) after implementation of preventive measures in patients with multiple myeloma treated with zoledronic acid. Ann. Oncol. 2009, 20, 117-120. [CrossRef] [PubMed] 
51. Haidar, A.; Jonler, M.; Folkmar, T.B.; Lund, L. Bisphosphonate (zoledronic acid)-induced osteonecrosis of the jaw. Scand. J. Urol. Nephrol. 2009, 43, 442-444. [CrossRef] [PubMed]

52. Ripamonti, C.I.; Maniezzo, M.; Campa, T.; Fagnoni, E.; Brunelli, C.; Saibene, G.; Bareggi, C.; Ascani, L.; Cislaghi, E. Decreased occurrence of osteonecrosis of the jaw after implementation of dental preventive measures in solid tumour patients with bone metastases treated with bisphosphonates. The experience of the National Cancer Institute of Milan. Ann. Oncol. 2009, 20, 137-145. [CrossRef] [PubMed]

53. Vahtsevanos, K.; Kyrgidis, A.; Verrou, E.; Katadritou, E.; Triaridis, S.; Andreadis, C.G.; Boukovinas, I.; Koloutsos, G.E.; Teleioudis, Z.; Kitikidou, K.; et al. Longitudinal cohort study of risk factors in cancer patients of bisphosphonate-related osteonecrosis of the jaw. J. Clin. Oncol. 2009, 27, 5356-5362. [CrossRef] [PubMed]

54. Fizazi, K.; Lipton, A.; Mariette, X.; Body, J.J.; Rahim, Y.; Gralow, J.R.; Gao, G.; Wu, L.; Sohn, W.; Jun, S. Randomized phase II trial of denosumab in patients with bone metastases from prostate cancer, breast cancer, or other neoplasms after intravenous bisphosphonates. J. Clin. Oncol. 2009, 27, 1564-1571. [CrossRef] [PubMed]

55. Bonomi, M.; Nortilli, R.; Molina, A.; Sava, T.; Santo, A.; Caldara, A.; Cetto, G.L. Renal toxicity and osteonecrosis of the jaw in cancer patients treated with bisphosphonates: A long-term retrospective analysis. Med. Oncol. 2009, 27, 224-229. [CrossRef] [PubMed]

56. Stumpe, M.R.; Chandra, R.K.; Yunus, F.; Samant, S. Incidence and risk factors of bisphosphonate-associated osteonecrosis of the jaws. Head Neck 2009, 31, 202-206. [CrossRef] [PubMed]

57. Gimsing, P.; Carlson, K.; Turesson, I.; Fayers, P.; Waage, A.; Vangsted, A.; Mylin, A.; Gluud, C.; Juliusson, G.; Gregersen, H.; et al. Effect of pamidronate $30 \mathrm{mg}$ versus $90 \mathrm{mg}$ on physical function in patients with newly diagnosed multiple myeloma (Nordic Myeloma Study Group): A double-blind, randomised controlled trial. Lancet Oncol. 2010, 11, 973-982. [CrossRef]

58. Pavkovic, M.; Petrushevska, G.; Jovanovic, R.; Karanfilski, O.; Cevreska, L.; Stankovic, S.; Stojanovic, A. Osteonecrosis of the jaw in patients with multiple myeloma treated with bisphosphanates. Prilozi 2010, 31, 39-49. [PubMed]

59. Stopeck, A.T.; Lipton, A.; Body, J.J.; Steger, G.G.; Tonkin, K.; de Boer, R.H.; Lichinitser, M.; Fujiwara, Y.; Yardley, D.A.; Viniegra, M.; et al. Denosumab compared with zoledronic acid for the treatment of bone metastases in patients with advanced breast cancer: A randomized, double-blind study. J. Clin. Oncol. 2010, 28, 5132-5139. [CrossRef] [PubMed]

60. Fizazi, K.; Carducci, M.; Smith, M.; Damião, R.; Brown, J.; Karsh, L.; Milecki, P.; Shore, N.; Rader, M.; Wang, H.; et al. Denosumab versus zoledronic acid for treatment of bone metastases in men with castration-resistant prostate cancer: A randomised, double-blind study. Lancet 2011, 377, 813-822. [CrossRef]

61. Quispe, D.; Shi, R.; Burton, G. Osteonecrosis of the jaw in patients with metastatic breast cancer: Ethnic and socio-economic aspects. Breast J. 2011, 17, 510-513. [CrossRef] [PubMed]

62. Ding, X.; Fan, Y.; Ma, F.; Li, Q.; Wang, J.; Zhang, P.; Yuan, P.; Xu, B. Prolonged administration of bisphosphonates is well-tolerated and effective for skeletal-related events in Chinese breast cancer patients with bone metastasis. Breast 2012, 21, 544-549. [CrossRef] [PubMed]

63. Miyazaki, H.; Nishimatsu, H.; Kume, H.; Suzuki, M.; Fujimura, T.; Fukuhara, H.; Enomoto, Y.; Ishikawa, A.; Igawa, Y.; Hirano, Y.; et al. Leukopenia as a risk factor for osteonecrosis of the jaw in metastatic prostate cancer treated using zoledronic acid and docetaxel. BJU Int. 2012, 110, E520-E525. [CrossRef] [PubMed]

64. Smith, M.R.; Saad, F.; Coleman, R.; Shore, N.; Fizazi, K.; Tombal, B.; Miller, K.; Sieber, P.; Karsh, L.; Damião, R.; et al. Denosumab and bone-metastasis-free survival in men with castration-resistant prostate cancer: Results of a phase 3, randomised, placebo-controlled trial. Lancet 2012, 379, 39-46. [CrossRef]

65. Thumbigere-Math, V.; Tu, L.; Huckabay, S.; Dudek, A.Z.; Lunos, S.; Basi, D.L.; Hughes, P.J.; Leach, J.W.; Swenson, K.K.; Gopalakrishnan, R. A retrospective study evaluating frequency and risk factors of osteonecrosis of the jaw in 576 cancer patients receiving intravenous bisphosphonates. Am. J. Clin. Oncol. 2012, 35, 386-392. [CrossRef] [PubMed]

66. Rugani, P.; Luschin, G.; Jakse, N.; Kirnbauer, B.; Lang, U.; Acham, S. Prevalence of bisphosphonate-associated osteonecrosis of the jaw after intravenous zoledronate infusions in patients with early breast cancer. Clin. Oral Investig. 2014, 18, 401-407. [CrossRef] [PubMed] 
67. Then, C.; Hörauf, N.; Otto, S.; Pautke, C.; von Tresckow, E.; Röhnisch, T.; Baumann, P.; Schmidmaier, R.; Bumeder, I.; Oduncu, F.S. Incidence and risk factors of bisphosphonate-related osteonecrosis of the jaw in multiple myeloma patients having undergone autologous stem cell transplantation. Onkologie 2012, 35, 658-664. [CrossRef] [PubMed]

68. Martin, M.; Bell, R.; Bourgeois, H.; Brufsky, A.; Diel, I.; Eniu, A.; Fallowfield, L.; Fujiwara, Y.; Jassem, J.; Paterson, A.H.; et al. Bone-related complications and quality of life in advanced breast cancer: Results from a randomized phase III trial of denosumab versus zoledronic acid. Clin. Cancer Res. 2012, 18, 4841-4849. [CrossRef] [PubMed]

69. Henry, D.H.; Costa, L.; Goldwasser, F.; Hirsh, V.; Hungria, V.; Prausova, J.; Scagliotti, G.V.; Sleeboom, H.; Spencer, A.; Vadhan-Raj, S.; et al. Randomized, double-blind study of denosumab versus zoledronic acid in the treatment of bone metastases in patients with advanced cancer (excluding breast and prostate cancer) or multiple myeloma. J. Clin. Oncol. 2011, 29, 1125-1132. [CrossRef] [PubMed]

70. Saad, F.; Brown, J.E.; Van Poznak, C.; Ibrahim, T.; Stemmer, S.M.; Stopeck, A.T.; Diel, I.J.; Takahashi, S.; Shore, N.; Henry, D.H.; et al. Incidence, risk factors, and outcomes of osteonecrosis of the jaw: Integrated analysis from three blinded active-controlled phase III trials in cancer patients with bone metastases. Ann. Oncol. 2012, 23, 1341-1347. [CrossRef] [PubMed]

71. Assaf, A.T.; Smeets, R.; Riecke, B.; Weise, E.; Groebe, A.; Blessmann, M.; Steiner, T.; Wikner, J.; Friedrich, R.E.; Heiland, M.; et al. Incidence of bisphosphonate-related osteonecrosis of the jaw in consideration of primary diseases and concomitant therapies. Anticancer Res. 2013, 33, 3917-3924. [PubMed]

72. Coleman, R.E.; de Boer, R.; Eidtmann, H.; Llombart, A.; Davidson, N.; Neven, P.; von Minckwitz, G.; Sleeboom, H.P.; Forbes, J.; Barrios, C.; et al. Zoledronic acid (zoledronate) for postmenopausal women with early breast cancer receiving adjuvant letrozole (ZO-FAST study): Final 60-month results. Ann. Oncol. 2013, 24, 398-405. [CrossRef] [PubMed]

73. Brufsky, A.M.; Sereika, S.M.; Mathew, A.; Tomifumi, O.; Singh, V.; Rosenzweig, M. Long-term Treatment with Intravenous Bisphosphonates in Metastatic Breast Cancer: A Retrospective Study. Breast J. 2013, 19, 504-511. [CrossRef] [PubMed]

74. Rathbone, E.J.; Brown, J.E.; Marshall, H.C.; Collinson, M.; Liversedge, V.; Murden, G.A.; Cameron, D.; Bell, R.; Spensley, S.; Agrawal, R.; et al. Osteonecrosis of the jaw and oral health-related quality of life after adjuvant zoledronic acid: An Adjuvant Zoledronic Acid to Reduce Recurrence Trial subprotocol (BIG01/04). J. Clin. Oncol. 2013, 31, 2685-2691. [CrossRef] [PubMed]

75. Barrett-Lee, P.; Casbard, A.; Abraham, J.; Hood, K.; Coleman, R.; Simmods, P.; Timmins, H.; Wheatley, D.; Griffiths, G.; Murray, N. Oral ibandronic acid versus intravenous zoledronic acid in treatment of bone metasta-ses from breast cancer: A randomised, open label, non-inferiority phase 3 trial. Lancet Oncol. 2014, 15, 114-122. [CrossRef]

76. Coleman, R.; Cameron, D.; Dodwell, D.; Bell, R.; Wilson, C.; Rathbone, E.; Keane, M.; Gil, M.; Burkinshaw, R.; Grieve, R.; et al. Adjuvant zoledronic acid in patients with early breast cancer: Final efficacy analysis of the AZURE (BIG 01/04) randomised open-label phase 3 trial. Lancet Oncol. 2014, 15, 997-1006. [CrossRef]

77. Jackson, G.H.; Morgan, G.J.; Davies, F.E.; Wu, P.; Gregory, W.M.; Bell, S.E.; Szubert, A.J.; Navarro Coy, N.; Drayson, M.T.; Owen, R.G.; et al. Osteonecrosis of the jaw and renal safety in patients with newly diagnosed multiple myeloma: Medical Research Council Myeloma IX Study results. Br. J. Haematol. 2014, 166, 109-117. [CrossRef] [PubMed]

78. Gnant, M.; Mlineritsch, B.; Stoeger, H.; Luschin-Ebengreuth, G.; Knauer, M.; Moik, M.; Jakesz, R.; Seifert, M.; Taucher, S.; Bjelic-Radisic, V.; et al. Austrian Breast and Colorectal Cancer Study Group, Vienna, Austria. Zoledronic acid combined with adjuvant endocrine therapy of tamoxifen versus anastrozol plus ovarian function suppression in premenopausal early breast cancer: Final analysis of the Austrian Breast and Colorectal Cancer Study Group Trial 12. Ann. Oncol. 2015, 26, 313-320. [PubMed]

79. Vidal-Real, C.; Pérez-Sayáns, M.; Suárez-Peñaranda, J.M.; Gándara-Rey, J.M.; García-García, A. Osteonecrosis of the jaws in 194 patients who have undergone intravenous bisphosphonate therapy in Spain. Med. Oral Patol. Oral Cir. Bucal 2015, 20, e267-e272. [CrossRef] [PubMed]

80. Rodrigues, P.; Hering, F.; Imperio, M. Safety of IV Nonnitrogen Bisphosphonates on the Occurrence of Osteonecrosis of the Jaw: Long-Term follow-up on Prostate Cancer Patients. Clin. Genitourin. Cancer 2015, 13, 199-203. [CrossRef] [PubMed] 
81. Stopeck, A.T.; Fizazi, K.; Body, J.J.; Brown, J.E.; Carducci, M.; Diel, I.; Fujiwara, Y.; Martín, M.; Paterson, A.; Tonkin, K.; et al. Safety of long-term denosumab therapy: Results from the open label extension phase of two phase 3 studies in patients with metastatic breast and prostate cancer. Support. Care Cancer 2016, 24, 447-455. [CrossRef] [PubMed]

82. Boquete-Castro, A.; Gómez-Moreno, G.; Calvo-Guirado, J.L.; Aguilar-Salvatierra, A.; Delgado-Ruiz, R.A. Denosumab and osteonecrosis of the jaw. A systematic analysis of events reported in clinical trials. Clin. Oral Implants Res. 2016, 27, 367-375. [CrossRef] [PubMed]

83. Cheng, A.; Mavrokokki, A.; Carter, G.; Stein, B.; Fazzalari, N.L.; Wilson, D.F.; Goss, A.N. The dental implications of bisphosphonates and bone disease. Aust. Dent. J. 2005, 50, S4-S13. [CrossRef] [PubMed]

84. Lazarovici, T.S.; Yahalom, R.; Taicher, S.; Elad, S.; Hardan, I.; Yarom, N. Bisphosphonate-related osteonecrosis of the jaws: A single-center study of 101 patients. J. Oral Maxillofac. Surg. 2009, 67, 850-855. [CrossRef] [PubMed]

85. Grötz, K.A.; Diel, I.J. Osteonekrose des Kiefers unter Bisphosphonat-Langzeittherapie. Im Focus Onkol. 2005, 3, 52-55.

86. Abu-Id, M.H.; Warnke, P.H.; Gottschalk, J.; Springer, I.; Wiltfang, J.; Acil, Y.; Russo, P.A.; Kreusch, T. "Bis-phossy jaws"-High and low risk factors for bisphosphonate-induced osteonecrosis of the jaw. J. Cranio-Maxillo-Fac. Surg. 2008, 36, 95-103. [CrossRef] [PubMed]

87. Otto, S.; Schreyer, C.; Hafner, S.; Mast, G.; Ehrenfeld, M.; Sturzenbaum, S.; Pautke, C. Bisphosphonate-related osteonecrosis of the jaws-Characteristics, risk factors, clinical features, localization and impact on oncological treatment. J. Cranio-Maxillo-Fac. Surg. 2012, 40, 303-309. [CrossRef] [PubMed]

88. Suleman, Y.F.; Meer, S.; Lurie, R. Bisphosphonate-induced osteonecrosis of the jaws: Review, clinical implications and case report. Head Neck Pathol. 2007, 1, 156-164. [CrossRef] [PubMed]

89. Ficarra, G.; Beninati, F.; Rubino, I.; Vannucchi, A.; Longo, G.; Tonelli, P.; Pini Prato, G. Osteonecrosis of the jaws in periodontal patients with a history of bisphosphonates treatment. J. Clin. Periodontol. 2005, 32, 1123-1128. [CrossRef] [PubMed]

90. Taylor, T.; Bryant, C.; Popat, S. A study of 225 patients on bisphosphonates presenting to the bisphosphonate clinic at King's College Hospital. Br. Dent. J. 2013, 214, E18. [CrossRef] [PubMed]

91. Saia, G.; Blandamura, S.; Bettini, G.; Tronchet, A.; Totola, A.; Bedogni, G.; Ferronato, G.; Nocini, P.F.; Bedogni, A. Occurrence of bisphosphonate-related osteonecrosis of the jaw after surgical tooth extraction. J. Oral Maxillofac. Surg. 2010, 68, 797-804. [CrossRef] [PubMed]

92. Niibe, K.; Ouchi, T.; Iwasaki, R.; Nakagawa, T.; Horie, N. Osteonecrosis of the jaw in patients with dental prostheses being treated with bisphosphonates or denosumab. J. Prosthodont. Res. 2015, 59, 3-5. [CrossRef] [PubMed]

93. Rahimi-Nedjat, R.K.; Sagheb, K.; Pabst, A.; Olk, L.; Walter, C. Diabetes Mellitus and Its Association to the Occurrence of Medication-Related Osteonecrosis of the Jaw. Dent. J. 2016, 4, 17. [CrossRef]

94. Beninati, F.; Pruneti, R.; Ficarra, G. Bisphosphonate-related osteonecrosis of the jaws (Bronj). Med. Oral Patol. Oral Cir. Bucal 2013, 18, e752-e758. [CrossRef] [PubMed]

95. Sim Ie, W.; Sanders, K.M.; Borromeo, G.L.; Seymour, J.F.; Ebeling, P.R. Declining Incidence of Medication-Related Osteonecrosis of the Jaw in Patients With Cancer. J. Clin. Endocrinol. Metab. 2015, 100, 3887-3893. [CrossRef] [PubMed]

96. Bagan, J.V.; Jimenez, Y.; Gomez, D.; Sirera, R.; Poveda, R.; Scully, C. Collagen telopeptide (serum CTX) and its relationship with the size and number of lesions in osteonecrosis of the jaws in cancer patients on intravenous bisphosphonates. Oral Oncol. 2008, 44, 1088-1089. [CrossRef] [PubMed]

97. Marx, R.E.; Cillo, J.E., Jr.; Ulloa, J.J. Oral bisphosphonate-induced osteonecrosis: Risk factors, prediction of risk using serum CTX testing, prevention, and treatment. J. Oral Maxillofac. Surg. 2007, 65, 2397-2410. [CrossRef] [PubMed]

(C) 2016 by the authors; licensee MDPI, Basel, Switzerland. This article is an open access article distributed under the terms and conditions of the Creative Commons Attribution (CC-BY) license (http:/ / creativecommons.org/licenses/by/4.0/). 